\title{
Rosyjskie nazwy realiów w ujęciu leksykograficzno-przekładowym
}

Do ważnych problemów translatorycznych i leksykograficznych należy przekład nazw realiów. Zgodnie z definicją podawaną w klasycznym dziele bułgarskich przekładoznawców - Siergieja Włachowa i Sidora Fłorina — realia ${ }^{1}$ to:

слова (и словосочетания), называющие объекты, характерные для жизни (быта, культуры, социального и исторического развития) одного народа и чуждые другому; будучи носителями национального и/или исторического колорита, они, как правило, не имеют точных соответствий (эквивалентов) в других языках, а, следовательно, не поддаются переводу на общем основании, требуя особого подхода (Włachow, Fłorin 2009: 49).

W literaturze przedmiotu można się spotkać również z innymi terminami, które przynajmniej częściowo pokrywają się z pojęciem nazw realiów. Są to między innymi leksyka bezekwiwalentowa (np. Tezaurus 1998: 173) i słowa z zerowym odpowiednikiem translatorycznym (Wojan 2007: 27). Dość często stosowany termin leksyki bezekwiwalentowej zawiera w sobie pewną sprzeczność z punktu widzenia leksykografii, gdyż dotyczy słów niemających swych stałych odpowiedników ${ }^{2}$ słownikowych, a jednak przez słowniki dwujęzyczne zazwyczaj odnotowywanych. Podobne zastrzeżenia można mieć do terminu leksyki z zerowym odpowiednikiem translatorycznym ${ }^{3}$.

${ }^{1}$ Autorzy monografii w języku rosyjskim posłużyli się terminem реалии. Natomiast z punktu widzenia polskiej terminologii właściwsze jest mówienie o nazwach realiów, co znajduje potwierdzenie w definicji sformułowanej przez Włachowa i Fłorina.

2 Terminy ekwiwalent i odpowiednik są przez nas traktowane synonimicznie.

3 Przytoczmy opinię Tadeusza Piotrowskiego o terminie ekwiwalencji zerowej w przekładzie: „W wypadku tłumaczenia mówienie o ekwiwalencji zerowej jest bezsensowne, każde bowiem wyrażenie języka A można jakoś przetłumaczyć na język B w ramach danego tekstu czy danej sytuacji” (Piotrowski 2011: 51). 
Uwagi te stanowią uzasadnienie dokonanego przez nas wyboru terminologicznego. Nazwy realiów są terminem węższym i bardziej jednoznacznym w porównaniu z wymienionymi, a także - niewartościującym, to znaczy nie zawierają żadnych sugestii odnośnie do możności / niemożności tłumaczenia lub znalezienia odpowiednika. Jest to o tyle ważne, że trudności w ekwiwalentyzacji nazw realiów należy rozpatrywać dla konkretnej pary języków z uwzględnieniem czynnika temporalnego ${ }^{4}$. Podkreślmy przy tym, że pojęcie nazw realiów należy odróżniać od tak zwanych luk leksykalnych (лакуньь w terminologii rosyjskiej). Zasadnicza różnica pomiędzy wymienionymi kategoriami polega na tym, że nazwy realiów oznaczają desygnat nieznany w kulturze docelowej, natomiast w przypadku luk leksykalnych desygnaty są znane, ale nie doczekały się nominacji (por. Iwanow, 2006: 97), na przykład w języku rosyjskim można mówić o czyichś braciach i siostrach, ale nie ma słowa odpowiadającego polskiemu rodzeństwo ${ }^{5}$.

Spróbujmy prześledzić sposoby ekwiwalentyzacji rosyjskich nazw realiów w Wielkim słowniku rosyjsko-polskim (Słownik PWN: 2004). Wybór właśnie tego dzieła jako obiektu do analizy został podyktowany kilkoma przesłankami. Słownik PWN to znacznie nowsze dzieło leksykograficzne od Wielkiego stownika rosyjsko-polskiego (Mirowicz et al. 1999) ${ }^{6}$ i zgodnie z deklaracją jego autorów ,jest pierwszym od niemal półwiecza dużym słownikiem ogólnym rosyjsko-polskim opracowanym od podstaw". Wydany nieco wcześniej przez wydawnictwo „Wiedza powszechna” Wielki słownik polsko-rosyjski (Hessen, Stypuła $1998^{7}$ ) oraz wymieniony słownik rosyjsko-polski tego samego wydawnictwa były wielokrotnie poddawane analizie krytycznej (m.in. Wawrzyńczyk 1987, 1992; Mędelska, Wawrzyńczyk 1992; Mędelska 1997; Bartwicka 2006). Wymienione prace, zaliczane do „nurtu konstruktywnej krytyki leksykograficznej" (Chlebda 2011: 40), przyczyniły się do opracowania nowej koncepcji nowoczesnego słownika rosyjsko-polskiego i polsko-rosyjskiego ${ }^{8}$. Analiza słownika PWN z założenia powinna być częściowo analizą pomysłów nowatorskich, a częściowo modyfikacji oraz przykładów powieleń rozwiązań znanych ze wcześniejszych słowników.

${ }^{4}$ Ta sama jednostka języka wyjściowego może nie mieć stałego odpowiednika w języku X, ale posiadać odpowiednik słownikowy w języku Y, czy to ze względu na zbieżność uwarunkowań, czy też dłuższą tradycję przekładową. Fakt tłumaczenia tekstów i tworzenia słowników sprzyja zawężeniu obszaru „,bezekwiwalentności” pomiędzy dwoma językami.

${ }^{5}$ Luki leksykalne siłą rzeczy muszą być wypełniane jednostkami wielowyrazowymi, np. ros. гнусавить może być zastąpione pol. mówić przez nos itd.

${ }^{6}$ Pierwsze wydanie ukazało się w $1970 \mathrm{r}$.

${ }^{7}$ Pierwsze wydanie $-1967 \mathrm{r}$.

8 ,Świadomie polemiczne konkretne nawiązania i rozwiązania strukturalnoleksykograficzne mają precedens w polskiej leksykografii dwujęzycznej: słowniki Wawrzyńczyk et al. 2004 i Wawrzyńczyk et al. 2005 powstały w określonej koncepcyjnej opozycji względem słowników: Bogusławski 1993, Hessen, Stypuła 1998 i Mirowicz et al. 1999” (Wawrzyńczyk 2011: 171). 
Przegląd rozwiązań zastosowanych w słowniku PWN należy poprzedzić kilkoma uwagami wstępnymi. Niektórzy badacze stosują zamiennie terminy słownik dwujęzyczny i słownik przekładowy (por. Palikowa 2007: 15). Inni próbują je różnicować (np. Zgusta 2006: 257-259). W niniejszym artykule termin słownik przekładowy będzie stosowany w znaczeniu specjalnego rodzaju słownika dwujęzycznego przeznaczonego przede wszystkim dla tłumaczy i uwzględniającego ich potrzeby. Odpowiada to stanowisku zajmowanemu przez niektórych polskich językoznawców. Roman Lewicki stwierdza wprost, że

słownik przekładowy nie jest tym samym, co słownik dwujęzyczny. Oczywiście słownik przekładowy jest dwujęzyczny, jednak jego zasadnicze cechy wynikają z podporządkowania takiego słownika celom tłumaczenia. Dlatego słownik przekładowy nie tyle podaje statyczne relacje między wyrażeniami (z reguły: pomiędzy wyrazami) obu języków, ile pokazuje możliwość przetłumaczenia danego wyrażenia (przy czym niekoniecznie wyrazu!) na język docelowy (Lewicki 2011: 159).

Podstawowym warunkiem stawianym słownikowi przekładowemu jest podawanie ekwiwalentów, które mogą być bezpośrednio wykorzystywane w tłumaczeniu tekstów, oraz wprowadzanie różnego rodzaju dodatkowych informacji, umożliwiających właściwą interpretację translandu, poprawne użycie translatu oraz ewentualnie zawierających pewien algorytm działania, pozwalający na uzyskanie za pomocą określonych transformacji właściwego odpowiednika tekstowego. Dlatego też niezwykle istotny jest wyraźny rozdział informacji stricte przekładowej, czyli wskazania konkretnego ekwiwalentu, od informacji dodatkowych ${ }^{9}$.

W słowniku PWN podjęta została próba wyraźnego rozgraniczenia ekwiwalentu od informacji dodatkowej w postaci systemu uwag nawiasowych — dyrektyw wyboru w języku rosyjskim oraz wskazówek interpretacyjnych w języku polskim przy bardzo ograniczonym zastosowaniu kwalifikatorów stylistycznych i dziedzinowych ${ }^{10}$.

Prześledźmy sposoby ekwiwalentyzacji rosyjskich nazw realiów zastosowane w słowniku PWN, ustalając, na ile autorom słownika napisanego ,zupełnie na nowo i po nowemu" (Słownik PWN 2004: 7) udało się odejść od przestarzałych i nieefektywnych rozwiązań leksykograficznych w zakresie omawianej przez nas grupy leksykalnej i wypracować metody nowoczesnej leksykografii przekładowej.

${ }^{9}$ Jak stwierdza Wojciech Chlebda: „Artykuł hasłowy słownika przekładowego powinien zawierać zarówno elementy ekwiwalencyjne, jak i elementy eksplikacyjne (Chlebda 1984), nie ulega jednak wątpliwości, że są to elementy różnogatunkowe, należące do odmiennych porządków informacyjnych i jako takie powinny być od siebie skrupulatnie i konsekwentnie oddzielane" (Chlebda 1997: 23-66).

${ }^{10}$ Wynika to zapewne z koncepcji wymienionego słownika, o czym świadczą słowa samych autorów: „Leksykografowie szafują zwłaszcza kwalifikatorami dziedzinowymi, zakresowymi, które są zupełnie zbędne wówczas, gdy zarówno transland, jak i translat odnoszą się do tej samej dziedziny wiedzy ludzkiej. Odrzucając je, czynimy tekst artykułu przejrzystszym, oszczędniejszym" (Wawrzyńczyk et al. 2007: 5). 


\section{Transkrypcja}

Do podstawowych sposobów oddawania nazw realiów w przekładzie z języka rosyjskiego zalicza się transkrypcję, rzadziej transliterację. Stosowana przez tłumaczy pozwala na wprowadzanie do tekstów egzotyzmów ${ }^{11}$, które niekiedy mogą utrwalać się jako stałe odpowiedniki przekładowe.

W słowniku PWN znajdujemy pewną liczbę przetranskrybowanych odpowiedników, dublowanych przez (najczęściej ponadleksykalny) bliskoznaczny ekwiwalent lub opatrzonych wskazówkami interpretacyjnymi, przykładowo:

коммуналка [-лки; род. мн. -лок] komunałka / mieszkanie wielorodzinne субботник [-ка] subotnik (czyn społeczny wykonywany zwykle w sobote).

Praktyka transkrybowania pojedynczych nazw realiów wymaga kilku komentarzy. Wydaje się, że autorzy słownika winni sygnalizować jego użytkownikowi status ekwiwalentu w języku polskim, a więc różnicować neutralne ekwiwalenty — zapożyczenia lub też słowa funkcjonujące na prawach egzotyzmów od doraźnie wprowadzonych odpowiedników, które poza określonym kontekstem lub też bez odpowiedniego komentarza nie funkcjonują samodzielnie w polszczyźnie. Taka dyferencjacja mogłaby być zaznaczona kursywą, na przykład коммуналка - komunatka ${ }^{12} \mathrm{w}$ odróżnieniu od możliwego zapisu дача — dacza.

Niektóre uwagi nawiasowe są bardzo rozbudowane. Przytoczone wyżej hasło субботник mogłoby mieć inny układ: subotnik / czyn społeczny (zwykle w sobotę). W takiej formie jest ono bardziej zwięzłe, a co najważniejsze zawiera polski odpowiednik przekładowy leksemu rosyjskiego jako jeden z wariantów. Sporna jednocześnie pozostaje kwestia kolejności — na pierwszym miejscu wskazywany jest odpowiednik trafniejszy, a więc bardziej uniwersalny. Subotnik oddaje koloryt leksemu rosyjskiego, nie należy jednak do słów powszechnie w polszczyźnie używanych ${ }^{13}$, natomiast neutralny czyn społeczny nieco zmienia konotacje, odsyłając odbiorcę raczej do rzeczywistości PRL-u niż ZSRR lub współczesnej Rosji czy Białorusi.

Stosowanie transkrypcji lub bezpośrednie przenoszenie leksemów z języków posługujących się alfabetem łacińskim jest obecnie zauważalną tendencją przekładową w zakresie nazw kulinarnych (por. pasta, kebab, sushi, bliny). Autorzy słownika PWN nie są jednak zupełnie konsekwentni. Słownik PWN zawiera hasło тюря [-ри] tiuria (potrawa z chleba wkruszonego do kwasu

${ }^{11}$ Egzotyzm należy rozumieć jako wyraz zapożyczony z danego języka dla oznaczenia realiów kraju, w którym ten język funkcjonuje (np. samuraj, sombrero).

12 Możliwe, że właściwsze byłoby zastosowanie kwalifikatora, specjalnego symbolu lub cudzysłowu.

13 Takiej jednostki nie notuje ani USJPD, ani WSJPD. Natomiast użycia tekstowe mogą być bardzo specyficzne, jak w przypadku żartobliwej nazwy stałego felietonu Rafała Ziemkiewicza w tygodniku „Do Rzeczy” — Subotnik Ziemkiewicza. 
chlebowego, wody lub mleka), w którym nazwa raczej mało znanej w Polsce potrawy ma przetranskrybowany odpowiednik i rozbudowaną nawiasową wskazówkę interpretacyjną. Przetranskrybowany ekwiwalent wraz z obszernym komentarzem pozwala na zrozumienie znaczenia i użycia leksemu wyjściowego, ale nie całkiem jest jasne, czy sam ekwiwalent słownikowy może być użyty w charakterze ekwiwalentu tekstowego. Jeśli trzeba wykorzystać część uwagi nawiasowej w tłumaczeniu tekstu, to oznacza to, że w tym przypadku mamy jednak do czynienia z odpowiednikiem opisowym. Co ciekawe, bardzo podobne rozwiązanie zostało zastosowane dla hasła кутья [-тьи] (кушанье), kutia (potrawa z ziaren pszenicy z rodzynkami, miodem). Jest to o tyle dziwne, że translat $\mathrm{w}$ odróżnieniu od poprzedniego notują słowniki języka polskiego ${ }^{14}$ i jako nazwa potrawy wigilijnej jest on znany przeciętnemu użytkownikowi polszczyzny. Identyczny status translatów tiuria i kutia w słowniku PWN nie odpowiada miejscu zajmowanemu przez nie w systemie leksykalnym języka polskiego. Zgodnie ze wcześniejszymi uwagami translat tiuria należałoby wyodrębnić graficznie, sugerując odbiorcy węższe użycie jednostki i konieczność zasygnalizowania jej obcości oraz ewentualnego zastosowania transformacji translatorycznych.

Z kolei obecne w słowniku PWN translaty kutia i blin mają zbliżony status w języku polskim. Drugi z wymienionych leksemów w USJPD został opatrzony kwalifikatorem reg., ale ponadto - wil. oraz ros. ${ }^{15}$. Ten ostatni wskazuje na rosyjskie pochodzenie słowa, prowadząc do wniosku, że funkcjonuje ono w polszczyźnie dwojako - jako regionalizm oraz na prawach egzotyzmu. To leksykograf musi dokonać interpretacji i od jego decyzji zależy ostateczny kształt hase ${ }^{16}$. Wskazana jednak byłaby konsekwencja. Przytoczone argumenty przemawiają za tym, żeby obydwa hasła miały zbliżoną budowę i nie zawierały obszernych wskazówek interpretacyjnych.

Przykłady niekonsekwencji widzimy również w innych hasłach zawierających nazwy rosyjskich potraw. Porównajmy:

окрошка [-ки] chłodnik (rosyjski: na kwasie, bez boćwiny, z mięsem lub $r y b a$ ), ale јuż пельмени [-меней; ед. -мень, -меняя] kołduny.

Obydwie potrawy są bardziej znane w Polsce niż тюря, ale w ani jednym przypadku autorzy nie decydują się na transkrypcję (nawet jako wariant). Przy

${ }^{14}$ kutia, kucja 〈ukr.> reg. lwow. krak. »tradycyjna potrawa wigilijna, znana zwłaszcza na Rusi i Litwie, przyrządzana z gotowanej pszenicy, kaszy lub ryżu, z utartym makiem, zwykle $\mathrm{z}$ dodatkiem miodu i bakalii« (USJPD).

${ }^{15}$ blin 〈ros.〉 reg. wil. »placek z ciasta drożdżowego, przygotowanego z mąki gryczanej, żytniej lub pszennej, smażony na tłuszczu«.

${ }^{16}$ W słowniku PWN: блин [-на] blin. Trudno rozstrzygnąć, czy nie byłoby właściwsze zachowanie również odpowiednika funkcjonalnego: блин [-на] blin / naleśnik. Pomijamy kwestię nieuwzględnienia znaczeń potocznych rosyjskiego leksemu. 
pierwszym haśle mamy informację encyklopedyczną. Trudno rozstrzygnąć, czy można zastosować w przekładzie ,goły” translat (w każdym razie oznaczałoby to utratę kolorytu i generalizację znaczenia), czy też należy użyć któregoś z określeń. W drugim przykładzie widzimy odpowiednik funkcjonalny.

Wydaje się, że w tych przypadkach należy zróżnicować ekwiwalencję, podając zarówno nazwy transkrybowane, jak i odpowiedniki wskazane przez autorów słownika. Przykładem zastosowania wariantów po prawej stronie słownika jest hasło вареник [-ка; вареники, -ков] pierożek / pieróg / warienik. Również ono wymaga jednak pewnej refleksji. Być może zbędny jest odpowiednik pierożek, a na pewno nie powinien on się znaleźć na pierwszym miejscu. Poza tym nowoczesny słownik przekładowy powinien informować o typowym realnym użyciu tekstowym jednostek. W związku z tym wyraz hasłowy należało podać w liczbie mnogiej, np. вареники ${ }^{17}$ (ед. ч. вареник) pierogi / warieniki.

\section{Odpowiednik opisowy}

Tłumacze oraz autorzy słowników w poszukiwaniu ekwiwalentu dla konkretnej nazwy realiów niekiedy uciekają się do odpowiednika opisowego. Mimo dość oczywistych wad — zwiększenie objętości tekstu, obniżenie ekspresywności i zwięzłości komunikatu — zabieg ten niekiedy pozostaje jedynym możliwym rozwiązaniem. Zwraca uwagę to, że słownik PWN zawiera pewną liczbę problematycznych pod względem użycia w przekładzie odpowiedników opisowych, przykładowo:

дружинник [-ка] członek obywatelskiej służby porządkowej

силовик [-ка] pазг. zwierzchnik resortu siłowego (wojskowego, w Rosji)

целинник [-ка] pionier zagospodarowujący caliznę (ziemie nie uprawiane, ugory).

Może to świadczyć o obiektywnym braku bardziej naturalnych odpowiedników na danym etapie rozwoju rosyjsko-polskich relacji przekładowych, co w pewnym stopniu usprawiedliwia obecność takich ekwiwalentów jako swoistego zła koniecznego.

Sytuacją zbliżoną do zastosowania ekwiwalentu opisowego jest opatrzenie jednosłownego odpowiednika bardzo rozbudowanymi uwagami nawiasowymi. Zbliżoną, gdyż najprawdopodobniej w przekładzie konieczne jest użycie przynajmniej części tego opisu, a więc w praktyce mamy do czynienia z próbą ukrycia ekwiwalentu opisowego w nawiasie, przeznaczonym do właściwej interpretacji translemu, ale niezawierającego z założenia gotowego ekwiwalentu.

${ }^{17}$ W NWSOJRK wyraz hasłowy to вареники, а nie вареник. 
Porównajmy:

камилавка [-вки; род. мн. -вок] kamiławka (nakrycie głowy duchownego prawosławnego otrzymywane za specjalne zastugi)

лимита [-ты] разг. przybysz z prowincji (specjalista, fachowiec itp. uzyskujący zameldowanie $w$ zamkniętym mieście, np. Moskwie, dzięki swoim deficytowym kwalifikacjom) ${ }^{18}$.

любер [-ра; люберы, -ров и любера, -po] lubierowiec (członek subkultury młodzieżowej, która przyjęła nazwę od miasta Lubierce pod Moskwa)

маниловщина [-ны] maniłowszczyzna (bezczynny błogostan - od nazwiska Maniłowa, postaci z powieści „,Martwe dusze” M. Gogola)

масленица [-цы] ostatki lm / zapusty lm (ostatni tydzień przed Wielkim Postem, podczas którego wyznawcom prawosławia nie wolno jeść mięsa, ale wolno ser, masto i ryby)

миропомазание [-ния] bierzmowanie (symboliczne namaszczenie olejem świętym na znak przyjęcia do wspólnoty chrześcijańskiej, następujące w kościele prawosławnym bezpośrednio po chrzcie)

Odnotujmy, jak się wydaje, niezupełnie udaną próbę ekwiwalentyzacji:

электричка [-чки; род. мн. -чек] разг. pociąg elektryczny (podmiejski) / elektryczny (podmiejski)

- на электричке (напр. ехать) pociągiem elektrycznym.

W świadomości użytkownika języka rosyjskiego электричка to potoczne określenie pociągu podmiejskiego. Wydaje się, że hasło mogłoby zostać zmodyfikowane:

электричка [-чки; род. мн. -чек] разг. pociąg podmiejski (zazwyczaj elektryczny).

18 Odrębną kwestią jest sposób formułowania tego typu wskazówek interpretacyjnych (w swojej istocie są to definicje encyklopedyczne). Narzuca się pytanie, czy nie da się ich formułować bardziej lapidarnie i precyzyjnie (лимита to najczęściej robotnik, a nie specjalista); miasto zamknięte w rzeczywistości radzieckiej i postradzieckiej raczej kojarzy się z miejscowościami, do których ograniczano wjazd (system przepustek) ze względu na obecność zakładów przemysłu zbrojeniowego lub obiektów wojskowych o szczególnym znaczeniu, a nie z Moskwą, którą tylko metaforycznie można nazwać miastem zamkniętym, gdyż problematyczny mógł być dłuższy pobyt (obowiązek meldunkowy). Rosyjski leksem ma odcień pejoratywny, czego odbiorca się nie dowie. Może za to wnioskować, że лимита to absolutny synonim лимитчика, skoro obydwa translandy mają identyczny (bardzo rozbudowany przecież, opatrzony kwalifikatorem i definicją) translat. Rosyjski leksem to pogardliwe określenie przybysza z prowincji przez mieszkańca np. Moskwy. W interpretacji słownikowej - specjalista zawdzięczający zameldowanie swoim deficytowym umiejętnościom. Jak widać, znaczenia pragmatyczne i konotacyjne jednostek po lewej i prawej stronie słownika są bardzo odległe. 
Natomiast na pewno wymaga korekty odpowiednik związku wyrazowego, ponieważ zawiera nieuzasadniony hiperonim (pociąg elektryczny to przecież także pociąg dalekobieżny).

\section{Odpowiednik funkcjonalny}

Teoretycy przekładu wyróżniają również ekwiwalent funkcjonalny. Krzysztof Hejwowski podaje, że: „Zastosowanie ekwiwalentu funkcjonalnego polega na zastąpieniu nazwy (lub aluzji do) zjawiska lepiej znanego w kulturze docelowej” (Hejwowski 2006: 81). Jednocześnie polski przekładoznawca krytycznie odnosi się do stosowania „ekwiwalentów, które wyraźnie odwołują się do nacechowanych wzorców kulturowych obcych kulturze wyjściowej" (ibidem: 82). Za negatywny przykład takiego działania uznaje on zastąpienie pierogów ruskich słowem ravioli we francuskim przekładzie Raportu o stanie wojennym M. Nowakowskiego (ibidem).

Zgadzając się z opinią wymienionego badacza, należy krytycznie ocenić następujące hasło ze Słownika PWN:

морс [-ca (-cy)] płynny owoc (napój).

Płynny owoc to ekwiwalent ze wszech miar niewskazany — przenosi użytkownika do kontekstu polskiego, w dodatku ograniczonego czasowo - napój był popularny w latach PRL-u. Jak wynika $\mathrm{z}$ ankiet przeprowadzanych przez autora wśród studentów filologii rosyjskiej, określenie to nie jest młodszym użytkownikom polszczyzny w ogóle znane. Poza tym polski płynny owoc oznaczał zazwyczaj sok jabłkowy, natomiast rosyjski мopc jest napojem najczęściej robionym z żurawiny lub borówek.

Należało się posłużyć innym sposobem ekwialentyzacji, używając na przykład hiperonimu i wskazówki interpretacyjnej:

морс napój (najczęściej żurawinowy lub borówkowy).

Bardzo nieprecyzyjnie potraktowano leksem проводник:

проводник [-ка]

1. (человек; вещество) przewodnik

2. (железнодорожный служащий) konduktor

W drugim znaczeniu jest to opiekun wagonu sypialnego. Dlatego też właściwsze byłoby wskazanie następujących ekwiwalentów:

2. konduktor / steward ( $w$ wagonie sypialnym) / sleepingowy.

Nie można zakładać, że ekwiwalentyzacja słów należących do określonej grupy tematycznej (np. nazwy potraw) musi odbywać się według jednego mo- 
delu - na przykład zawsze transkrypcji, zawsze odpowiednika funkcjonalnego itd. Zróżnicowanie rodzajów translatów wynika z różnego stopnia znajomości leksemów wyjściowych przez użytkownika języka polskiego. Jednak przegląd rosyjskich nazw realiów w słowniku PWN wskazuje na nadmierną dowolność i niekonsekwencję w strategii doboru ekwiwalentów. Porównajmy:

блинная [-ной] smażalnia blinów
пельменная [-нной] (закусочная) kołduny
пирожковвая [-вой] bar z pasztecikami
чебуречная [-ной] bar serwujący czebureki

Чебуречная mogłaby zostać zastąpiona smażalnią czebureków; z równym powodzeniem ekwiwalentem leksemu блинная mógłby być bar serwujący bliny. Odpowiednik dla każdego z wymienionych lokali mógłby zostać utworzony według modelu bar z (odpowiednio: blinami, czeburekami, kołdunami). Zastanawia natomiast ekwiwalent kołduny. Przybliżony odpowiednik wskazany dla transladu пельмени tutaj pełni funkcję nazwy lokalu gastronomicznego. W typowym kontekście użycia, nр. мы сидели в пельменной — *siedzieliśmy w kotdunach jest on co najmniej wątpliwy. Można jedynie przypuszczać, że mamy do czynienia z próbą wskazania odpowiednika na poziomie napisu (szyldu) w dwóch językach. Jednak próba ta jest chybiona, ponieważ: nie ma wskazania na funkcję napisu, wskazówka interpretacyjna jednoznacznie informuje, że chodzi o rodzaj lokalu gastronomicznego.

\section{Wnioski}

Integralnym elementem nazw realiów jest obecność kolorytu oraz potencjału konotacyjnego. O ile koloryt, przynajmniej częściowo, może być zachowany dzięki zabiegowi transkrypcji, o tyle potencjał konotacyjny albo ulega neutralizacji (ekwiwalent opisowy), albo, co prawdopodobnie jest jeszcze mniej pożądane z punktu widzenia tłumacza, zostaje zmieniony ${ }^{19}$. W przypadku wielu nazw realiów wskazanie odpowiednika wywołującego te same bądź zbliżone konotacje jest niemożliwe. W procesie przekładu transformacje mogą doprowadzić do zachowania określonego wpływu pragmatycznego, przykładowo poprzez zabiegi kompensacyjne, przekład kontekstowy, ekwiwalent funkcjonalny (w zależności od strategii tłumacza i typu tekstu), ale są one możliwe do zastosowania tylko

19 Porównajmy рюмочная [-ной] winiarnia. W czasach radzieckich tak nazywano rodzaj lokalu gastronomicznego, w którym zazwyczaj stojąc spożywano alkohol (najczęściej wódkę) rozlewany do kieliszków (stąd nazwa) i kanapki. We współczesnej Rosji nazwa рюмочная mоże być użyta do oznaczenia lokalu o podobnej specyfice — do кафе (stoliki, kelnerzy, pełny asortyment potraw, włączając obiad i napoje bezalkoholowe i alkoholowe — od piwa po wódkę, od tanich po bardziej wyszukane). Wymienione użycia / znaczenia danego leksemu niewiele mają wspólnego z polskim winiarnia (w dodatku polisemicznym; konkretne znaczenie nie jest wskazane!). 
w przypadku uświadomienia sobie obecności owych konotacji. Tego typu informacji w słowniku PWN po prostu nie ma. Ewentualne ich włączenie do uwag nawiasowych z możliwym wykorzystaniem kwalifikatorów informujących o nacechowaniu stylistycznym, typowym użyciu i/lub konotacjach wzorowanych na rozwiązaniach znanych z leksykografii jednojęzycznej (np. Bańko 2000) - mówimy o; stowo uzywane $z$ dezaprobata itp. — zwiększyłoby walory praktyczne słownika, powiększając oczywiście jego rozmiary, i zbliżając go z teoretycznego punktu widzenia do słownika typu mieszanego — przekładowo-objaśniającego.

Wszystkie powyższe rozważania stanowią przyczynek do szerszej refleksji nad kształtem nowoczesnego słownika przekładowego. Jedno jest pewne: słownik dla tłumacza nie może ograniczać się do prostego wyliczania ekwiwalentów; jak słusznie zauważa Wojciech Chlebda: „Słownik przekładowy nie tylko przynosi odpowiednik drugojęzyczny, ale też stara się nieść podpowiedzi, jak przekładać, czyli jak za pomocą odpowiedników przekładowych tworzyć tekst w języku docelowym" (Chlebda 2014: 18). Do takich podpowiedzi należy zaliczyć informacje dodatkowe, umożliwiające właściwą interpretację, poprawne użycie jednostki docelowej, dokonanie niezbędnych transformacji, z utworzeniem na podstawie danych słownika nowego odpowiednika włącznie. Wśród dodatkowych informacji większy udział muszą mieć dane o łączliwości, konotacjach kulturowych i informacjach o charakterze realioznawczym. Należy zaznaczyć, że Słownik PWN niewielką część tego typu informacji zawiera (co go zbliża pod względem struktury do słownika typu mieszanego), ale — jak wykazaliśmy na podstawie analizy pojedynczych przykładów nazw realiów — podaje je w sposób wybiórczy i niekonsekwentny.

\section{Słowniki}

Bańko 2000: Inny słownik języka polskiego, red. M. Bańko, Warszawa, t. 1-2.

Bogusławski 1993: Ilustrowany stownik rosyjsko-polski, polsko-rosyjski, t. 1-2, wyd. 4, Warszawa. Hessen, Stypuła 1998: Wielki słownik polsko-rosyjski, t. 1-2, wyd. 5, Warszawa.

Mirowicz et al. 1999: A. Mirowicz, I. Dulewiczowa, I. Grek-Pabisowa, I. Maryniakowa, Wielki słownik rosyjsko-polski, t. 1-2, wyd. VI, Moskwa-Warszawa.

NWSOJRK 2008: Новейший большой толковый словарь русского языка, red. С.А. Кузнецов, Санкт-Петерсбург.

Słownik PWN 2004: Wielki słownik rosyjsko-polski z kluczem polsko-rosyjskim, red. J. Wawrzyńczyk, Warszawa.

Tezaurus 1998: Tezaurus terminologii translatorycznej, red. J. Lukszyn, Warszawa.

USJPD 2003: Uniwersalny słownik języka polskiego, red. S. Dubisz, Warszawa (wersja elektroniczna). Wojan 2007: Wojan K. przy udziale E. Skupińskiej-Dybek, Słownik homonimów leksemowych języka rosyjskiego z polskimi ekwiwalentami ttumaczeniowymi, Gdańsk.

WSJPD 2007: Współczesny słownik języka polskiego, red. B. Dunaj, Warszawa, t. 1-2.

\section{Literatura}

Bartwicka 2006: H. Bartwicka, Analiza semowa jako instrument doboru ekwiwalentów w stowniku dwujęzycznym, [w:] red. H. Bartwicka, Ze studiów konfrontatywno-przekładowych nad językiem polskim i rosyjskim, Warszawa, s. 7-17. 
Chlebda 1984: W. Chlebda, Nad koncepcja przekładowego słownika objaśniajacego, „Studia i Materiały WSP w Zielonej Górze XV, Filologia Rosyjska 3”, Zielona Góra, s. 203-212.

Chlebda 1997: W. Chlebda, Biblizmy języka polskiego i rosyjskiego. Koncepcje opisu leksykograficznego, [w:] Wspótczesny język polski i rosyjski. Konfrontacja przekładowa, red. A. Bogusławski, J. Mędelska, Warszawa, s. 23-66.

Chlebda 2011: W. Chlebda, Ekwiwalencja i ekwiwalenty: między stownikiem a tekstami, [w:] Na tropach translatów. W poszukiwaniu odpowiedników przekładowych, red. W. Chlebda, Opole, s. 21-43.

Chlebda 2014: W. Chlebda, Od tematycznego frazeologicznego stownika przektadowego do alfabetycznego stownika par przekładowych, [w:] Polsko-rosyjski słownik par przekładowych. Tom zbiorczy idiomatykonu polsko-rosyjskiego (z. 1-5), red. W. Chlebda, Opole, s. 18.

Hejwowski 2006: K. Hejwowski, Kognitywno-komunikacyjna teoria przekładu, Warszawa.

Iwanow 2006: А.О. Иванов, Безэквивалентная лексика, Санкт-Петербург.

Lewicki 2011: R. Lewicki, Translaty w słowniku przekładowym — poszukiwanie i ustalanie, [w:] Na tropach translatów. W poszukiwaniu odpowiedników przekładowych, red. W. Chlebda, Opole, s. 159-165.

Mędelska 1997: J. Mędelska, Refleksy polszczyzny pótnocnokresowej w Wielkim słowniku rosyjsko-polskim, [w:] Wspótczesny język polski i rosyjski. Konfrontacja przekładowa, red. A. Bogusławski, J. Mędelska, Warszawa, s. 81-105.

Mędelska, Wawrzyńczyk 1992: J. Mędelska, J. Wawrzyńczyk, Między oryginałem a przekładem: rzecz o słownikach dwujęzycznych, Kielce.

Palikowa 2007: О. Паликова, Двуязычный словарь и функиионально значимые связи слова, Тарту.

Piotrowski 2011: T. Piotrowski, Translaty w slowniku przekładowym - poszukiwanie i ustalanie, [w:] Na tropach translatów. W poszukiwaniu odpowiedników przekładowych, red. W. Chlebda, Opole, s. 45-69.

Wawrzyńczyk 1987: J. Wawrzyńczyk, Język rosyjski w stownikach polsko-rosyjskich powojennego czterdziestolecia, [w:] Z aktualnych studiów rusycystycznych. Językoznawstwo i glottodydaktyka, Olsztyn, s. 163-171.

Wawrzyńczyk 1992: J. Wawrzyńczyk, O rozwoju leksykografii rosyjsko-polskiej, „Przegląd Rusycystyczny" 1992, nr 3-4 (59-60), s. 53-63.

Wawrzyńczyk 2006a: J. Wawrzyńczyk, O rozwoju leksykografii rosyjsko-polskiej, [w:] O języku polskim i rosyjskim. Studia i szkice, red. J. Wawrzyńczyk, Łask, s. 139-153.

Wawrzyńczyk 2006b: J. Wawrzyńczyk, Wyrazy i zwroty zwiazane z życiem religijnym $w$,wielkiej" leksykografii rosyjsko-polskiej, [w:] O języku polskim i rosyjskim. Studia i szkice, red. J. Wawrzyńczyk, Łask, s. 265-271.

Wawrzyńczyk 2011: J. Wawrzyńczyk, Blaski i cienie translatosfery, [w:] Na tropach translatów. W poszukiwaniu odpowiedników przekładowych, red. W. Chlebda, Opole, s. 167-175.

Wawrzyńczyk et al. 2007: J. Wawrzyńczyk, H. Bartwicka, E. Małek, Wielki słownik rosyjsko-polski z kluczem polsko-rosyjskim. Wielki stownik polsko-rosyjski. Autokomentarze i erraty, Warszawa.

Włachow, Fłorin 2009: С.И. Влахов, С.П. Флорин, Непереводимое в переводе, wyd. 4, Москва. Zgusta 2006: L. Zgusta, Lexicography Then and Now. Selected Essays, Tübingen. 


\section{Russian language realia in the lexicographic and translation contexts}

\section{Summary}

The article discusses dictionary search methods and translation equivalents concerning Russian language realia. A critical analysis is conducted on the resources included in The Great Russian-Polish Dictionary edited by Jan Wawrzyńczyk. Inaccuracies found in dictionary entries, as well as inaccuracies in the choice of equivalence, allow us to formulate some conclusions about suitable methods to present realia in a modern Russian-Polish translation dictionary.

Keywords: translational dictionary, bilingual dictionary, realia, untranslated lexical items, lexicographical criticism.

\section{Реалии русского языка \\ в лексикографическо-переводческом ракурсе}

\section{Резюме}

В настоящей статье рассматриваются способы поиска словарных и переводческих эквивалентов для реалий русского языка. Критическому анализу подвергается материал Большого русско-польского словаря под редакцией Я. Вавжинчика. Выявленные недочёты в построении словарных статей, а также неточности в выборе соответствий, позволяют сформулировать некоторые выводы относительно методов презентации реалий в современном переводном русско-польском словаре.

Ключевые слова: переводной словарь, двуязычный словарь, реалии, безэквивалентная лексика, лексикографическая критика. 